\title{
PIXE FOR ElEMENTAL ANALYSIS OF DOMESTIC MEdicinal Plants in BANGLADESH
}

\author{
Md. Lokman Hossen ${ }^{1}$, Md. Joynal Abedin ${ }^{2}$, Shirin Akter ${ }^{3}$ \\ ${ }^{1}$ Department of Physics, University of Barisal, Barisal, Bangladseh \\ ${ }^{2 \& 3}$ Accelerator Facilities Division, Atomic Energy Center (AECD), Dhaka, Bangladesh
}

\begin{abstract}
The medicinal plants are a source of biologically important elements which are necessary both for animals and plants. Present study investigates the concentration of elemental constituents of seven selected medicinally important plants of Bangladesh, namely Terminalia bellirica, Centella asiatica, Pleurotus ostreatus, Curcuma longa, Bombax ceiba and Trigonella foenum-graecum. Appropriately desiccated samples (pellets) of these medicinal plants were bombarded with accelerated proton beam with the help of 3 MV Van de Graff accelerator at accelerator Facilities Division, Atomic Energy Center, Dhaka. Eleven different elements- $P, S, K, C a, S c, T i, V, M n, F e, C d$ and I were detected by collecting the harvested X-rays with [Si(Li)] detector. Data collection and analysis were performed using Maestro-32 and GUPIX software.
\end{abstract}

\section{KEYWORDS}

Medicinal plant, PIXE, X-rays, elemental, Si(Li) detector.

\section{INTRODUCTION}

Men are blessed with varieties of plants on the earth and medicinal plants are, perhaps, the creator's best blessings upon men. The plants which are used as medicine or in veterinary practices are called medicinal plants. Bangladesh is decked with varieties of medicinal plants (about seven hundred and twenty-two plants) which are being used frequently as a curative agent by the Bangladeshi people [1]. Not only in Bangladesh but also throughout the world medicinal plants have been being venerated greatly by the people as healing or treating substances since the period of embryonic evolution of human being. In few cases, medicinal plants are not used any more as more effective drugs are available. However, most of the medicinal plants are being used to synthesize useful drugs. The therapeutic properties of the medicinal plants have been ascribed to the presence of active chemical constituents (essential oils, vitamins etc.) which are responsible for important physiological function in living organisms [2]. It is customary that over dose may lead to aggregation of different elements into the body which causes various health disorders due to their poisonous effect [3], their deficiency causes diseases as well [4]. In this perspective, elemental concentration analysis of medicinal plants in vivo is very important. There is no complete report on the role of elements which are important to produce active chemical constituents bearing curative properties. Present pharmacological ideas can't describe the relation between elemental constituents of medicinal plants and their therapeutic potentiality. That is why quantitative analysis of different elemental concentrations may lead to perceive easily about the importance of medicinal plants in treating different disorders and to understand their remedial mystery [5].

DOI : $10.14810 /$ ijrap.2016.5401 


\section{SAMPLING AREA}

Among all the samples presented in Table 1 with other informations, Thankuni and Ulotkambol are collected from Jahangirnagar University campus, and Holud, Shimul and Methi were collected from Savar, and Mashroom was collected from Mashroom Development Centre, and Bohera was collected from Bangladesh Livestock Research Institute. All the three spots are situated at Savar Upozila under Dhaka district.

Table 1. Table of the medicinal plant's local name, English name, Scientific name family, parts used and their uses.

\begin{tabular}{|c|c|c|c|c|c|c|}
\hline No & $\begin{array}{l}\text { LOCAL } \\
\text { NAME }\end{array}$ & $\begin{array}{l}\text { ENGLISH } \\
\text { NAME }\end{array}$ & $\begin{array}{l}\text { SCIENTIFIC } \\
\text { NAME }\end{array}$ & FAMIIY & $\begin{array}{l}\text { PART } \\
\text { USED }\end{array}$ & MEDICINAL USES \\
\hline 01 & BOHERA & $\begin{array}{l}\text { BELLIRIC } \\
\text { MYROBALAN }\end{array}$ & $\begin{array}{l}\text { TERMMNALIA } \\
\text { BELLIRICA }\end{array}$ & COMGRETACEAE & FUUITS & $\begin{array}{l}\text { ABDONINAL DISEASES, BLEEDING EXTERNAL, } \\
\text { BALDNESS, CATARACT, BRONCHITIS, BLOOD } \\
\text { PURIFIERETC. }\end{array}$ \\
\hline 02 & THANKUNI & $\begin{array}{l}\text { ASTATIC } \\
\text { PENAYYORT }\end{array}$ & $\begin{array}{l}\text { CENTELLA } \\
\text { ASTATICA }\end{array}$ & APIACEAE & $\begin{array}{l}\text { AERIAL } \\
\text { PARTS }\end{array}$ & $\begin{array}{l}\text { ALZHEMMR, BURNS, AGING, ARTHRITIS, ADHD } \\
\text { (ATTENTION DEFCTT HYPERACTIVE DISORDEM } \\
\text { ETC. }\end{array}$ \\
\hline 03 & MashrRoOM & $\begin{array}{l}\text { OYSTER } \\
\text { MUSHROOM }\end{array}$ & $\begin{array}{l}\text { PLEUROTUS } \\
\text { OSTREATUS }\end{array}$ & PLEUROTACEAE & $\begin{array}{l}\text { AERIAL } \\
\text { PARTS }\end{array}$ & $\begin{array}{l}\text { BREAST CANCER DIABETES, DIGESTIVE } \\
\text { DISORDER, HEPATITIS, COLD, ANEMAA ETC. }\end{array}$ \\
\hline 04 & HOLUD & TURMERIC & $\begin{array}{l}\text { CURCUMA } \\
\text { LONGA }\end{array}$ & ZINGIBERACEAE & ROOTS & $\begin{array}{l}\text { FOOD POISONING, SNUUSTTS, ALLERGY, } \\
\text { ABDOMINAL MALIGNANCY, ACNE ETC. }\end{array}$ \\
\hline os & SHIMUr & $\begin{array}{l}\text { COTTON } \\
\text { TREF }\end{array}$ & $\begin{array}{l}\text { BOMBAX } \\
\text { CEIBA }\end{array}$ & MALVACEAE & $\mathrm{ROOTS}$ & $\begin{array}{l}\text { BURNS, ABSCESS, DIARRHOEA, DYSENTERY, } \\
\text { BREAST MLLR INSUFICIENCY ETC. }\end{array}$ \\
\hline 06 & METHI & FENUGREEK & $\begin{array}{l}\text { TRIGONELLA } \\
\text { FOENUM } \\
\text { GRAECUM }\end{array}$ & FABACEAE & SEEDS & $\begin{array}{l}\text { HERNIA, MPOTENCE, DIABETES, ACTD RERLUX, } \\
\text { ALZHEMMR, APPENDICITIS, ASTHMA, ANEMIA } \\
\text { ETC. }\end{array}$ \\
\hline
\end{tabular}

It is almost situated in the central region of Bangladesh and is located at $23^{\circ} 51^{\prime} 30^{\prime \prime} \mathrm{N}$ latitude and $90^{\circ} 16^{\prime} 00^{\prime \prime} \mathrm{E}$ longitude, and is about 24 kilometres away to the northwest of Dhaka city. The Upazila encompasses about $280.12 \mathrm{~km}^{2}$ area and most of which are used in industrial purposes. It's soil is mainly acidic with small rocks and yellowish to reddish in colour. In summer temperature is very high and April is found the hottest month with a maximum temperature of $33.9^{\circ} \mathrm{C}$. January is the coldest month with minimum temperature $14.1^{\circ} \mathrm{C}$. Humidity keeps remain in between 55-78\% (source: Meteorological Dept., Dhaka). There are many canals and ponds in Savar area but all are intoxicated with industrial dumping. In rainy season the pollution gets mild and acidic behaviour of soil also reduced. That's why samples were collected in rainy season. 


\subsection{SAMPle Preparation}

Six frequently used medicinal plants were collected and prepared carefully as no contamination can introduce further during the process. Thankuni, Ulotkambol and Mashroom samples were dried with temperature (50-80) ${ }^{0} \mathrm{C}$ for 48 hours, while the other four were dried with temperature of about $90{ }^{\circ} \mathrm{C}$ for about 100 hours with an oven "Memmert Schutzart DIN 40050 - IP 20". After ensuring about the complete dry and moisture free, the samples were grounded into powder with a mortar-pester to avoid chromium contamination from stainless steel devices. Again, in order to avoid cross contamination, after grinding each sample, the pester was cleaned with acetone $\left(\mathrm{CH}_{3}-\right.$ $\mathrm{CO}-\mathrm{CH}_{3}$ ). Each sample powder was then pelletized into pellet of $7 \mathrm{~mm}$ diameter and $2 \mathrm{~mm}$ thickness using hydraulic press with pressure $125 \mathrm{~kg} / \mathrm{cm}^{2}$.

\subsection{Methodology}

Among different analytical methods available in this technological age, such as atomic absorption, neutron activation technique, atomic emission, mass spectrometry, ion beam analytical (IBA) technique and chemical and electro analytical methods, a particular technique ion beam analytical technique has been selected. IBA technique is multi elemental and sensitive. Moreover, IBA methods are nondestructive means collected samples may be archived for future work or for regulatory purposes [6]. The technique involves the use of energetic ion beam to study the surface of a specimen to reveal details of the elemental details of its makeup. When high-energy charged particles hit a target there is a possibility of happening so many processes, such as Rutherford Back Scattering (RBS), Proton Induced X-ray Emission (PIXE), Proton Induced Gamma-ray Emission (PIGE), Nuclear Reaction Analysis (NRA) and Scattering Transmission Ion Microscopy (STIM). Among them PIXE is important and widely used analytical technique at $\mathrm{MeV}$ energy accelerator. The energetic proton beam from the accelerator tube hit the sample which causes X-ray emission is proportional to the mass of corresponding element in the sample being analyzed [7-8]. In our study, PIXE spectroscopy is carried out at 3 MV Van de Graff accelerator, Atomic Energy Center, Dhaka (AECD).

\subsection{IrRadiation And Data Collection}

All the pelletized medicinal plant samples were irradiated with $2.5 \mathrm{MeV}$ collimated Proton beams at the current intensity range of (10-20) nA using a $3 \mathrm{MV}$ Van de Graff accelerator. The emitted $\mathrm{X}$-rays in the irradiation were detected by using [Si(Li)] detector and the MAESTRO software was used to collect and save the signals in a specific file format(ORTEC).

\subsection{Data ANAlysis}

In PIXE method the data of different elements were assessed by analyzing the peaks from the spectrum saved by MAESTRO software of different X-rays by using GUPIX database [9]. GUPIX software was used to analyze PIXE spectra because of its good status of the databases, such as cross-sections, fluorescence and Coster-Kronig probabilities, stopping powers and attenuation coefficients $[10,11]$. The measured concentrations of the elements of the sample were calculated using the following well known equation:

$$
C_{s}=C_{s t} \frac{S_{s} Y_{s}}{S_{s t} Y_{s t}}
$$


Where, $\mathrm{C}_{\mathrm{s}}=$ concentration of the sample, $\mathrm{C}_{\mathrm{st}}=$ concentration of the standard sample, $\mathrm{S}_{\mathrm{s}}=$ stopping power of the sample, $S_{\mathrm{st}}=$ stopping power of the standard, $\mathrm{Y}_{\mathrm{s}}=$ yield of the sample and $\mathrm{Y}_{\mathrm{st}}=$ yield of the standard.

\section{RESULTS AND DISCUSSIONS}

Total 11 elements such as phosphorus, sulfur, potassium, calcium, scandium, titanium, vanadium, manganese, iron, cadmium and iodine were detected from the six different medicinal plant samples of Terminalia bellirica, Centella asiatica, Pleurotus ostreatus, Curcuma longa, Bombax ceiba and Trigonella foenum-graecum by bombarded them with a high energy of $2.5 \mathrm{MeV}$ proton beam. The measured concentrations found in the samples are presented in Table 2. and for a further clear presentation the concentrations of all the elements found in medicinal plant samples are illustrated together through bar diagram in Figure 1. The concentration of elements contained in sample plants are represented separately in Figure (2.1-2.6).

Table 2. Table of different elements contained in medicinal plants and their concentration in $\mathrm{mg} / \mathrm{kg}$.

\begin{tabular}{|c|c|c|c|c|c|c|c|c|c|c|c|c|}
\hline \multirow{2}{*}{$\begin{array}{l}\text { Seientife Neme } \\
\text { ef the Semyle }\end{array}$} & \multirow{2}{*}{$\begin{array}{l}\text { Leeal Neme of } \\
\text { the Sengla }\end{array}$} & \multicolumn{11}{|c|}{ 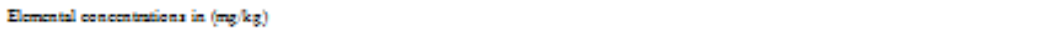 } \\
\hline & & $D$ & 3 & $\mathrm{x}$ & $\mathrm{Ca}$ & $3 e$ & $\mathrm{Ts}$ & $\mathrm{v}$ & 狏 & Fe & $\mathrm{Cd}$ & 1 \\
\hline $\begin{array}{l}\text { Teminalia } \\
\text { bellopes }\end{array}$ & Pabm & $\mathrm{ND}$ & 1255.7 & 2546.3 & 33722.5 & 50504.8 & 7435.1 & 250360 & $\mathrm{ND}$ & 7407.3 & $\mathrm{ND}$ & 451500 \\
\hline 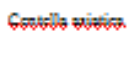 & Foweknow & 223077.3 & 1077328 & 3693.: & $1: 226.2$ & $367: .1$ & $\begin{array}{l}\text { 174a: } \\
3\end{array}$ & $\mathrm{ND}$ & 2323.0 & $\mathrm{ND}$ & 9379.5 & 969879 \\
\hline 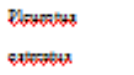 & Vephosen & $4013: 68$ & 57320.9 & 5436.4 & 18366.5 & $\mathrm{ND}$ & $\mathrm{ND}$ & 2255.8 & $\mathrm{ND}$ & $\mathrm{ND}$ & 24150.7 & $\mathrm{ND}$ \\
\hline Cuseume lenga & Helud. & 1967327 & 1693948 & 35606.3 & 40070.1 & 50573.9 & $\mathrm{ND}$ & 2545.6 & $\mathrm{ND}$ & 369.6 & $\mathrm{ND}$ & $\mathrm{ND}$ \\
\hline 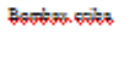 & stimed & 3ร62313 & $350772:$ & 2933:.4 & $\mathrm{ND}$ & $\mathrm{ND}$ & $\begin{array}{l}12535 . \\
3\end{array}$ & ND & $\mathrm{ND}$ & $\mathrm{ND}$ & $\mathrm{ND}$ & 1144020 \\
\hline 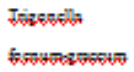 & Whiti & 3901782 & 2051517 & 51710 & 20730 & 22221.3 & 5796.6 & ND & 2953.4 & ND & ND & 122130 \\
\hline
\end{tabular}

Sulfur and potassium are found in every plant with the highest concentration of $350772.1 \mathrm{mg} / \mathrm{kg}$ and $51710 \mathrm{mg} / \mathrm{kg}$ respectively. Sulfur is very important in amino acid formation. Although it is less toxic for man irrespective of their concentration, sulfur made compounds may cause serious health hazard for animal tissues [12]. Potassium has the power to prevent stroke and treat high blood pressure by maintaining body's water balance [13]. Potassium is also used for the remedy of renal disorder and diarrhoea. Phosphorus and Calcium were detected in five medicinal plants with maximum concentration of $401316.8 \mathrm{mg} / \mathrm{kg}$ in Pleurotus ostreatus and $83722.5 \mathrm{mg} / \mathrm{kg}$ in Terminalia bellirica respectively. The large amount of phosphorus is significant for its important role in DNA synthesis, calcium absorption and energy metabolism [14]. Whatever the amount is, 
it has no toxic effect on human body. For the harder part of our body, e.g. bone, teeth calcium is considered as an essential nutrient. It is also important for muscle contraction, blood clotting, digestion and outside skeleton formation of organelles and membranes [15]. The highest measured concentrations of scandium, titanium and iodine are $50573.9 \mathrm{mg} / \mathrm{kg}$ in Curcuma longa, $17481.3 \mathrm{mg} / \mathrm{kg}$ in Centella asiatica and $96897.9 \mathrm{mg} / \mathrm{kg}$ in Centella asiatica. All the elements were found in four different medicinal plants. The rare earth element, scandium has no physiological and toxicological effect on human body but chronic renal failure [16]. Dental implantation and orthopedic surgery are two major fields where titanium is vastly used. Like scandium, titanium is also considered as safe metal for human health [17]. Iodine, an essential trace element, is required for man throughout the life. Iodine plays a very important role in different body functioning such as maturation of reproductive system and development of the body [18]. It is the constituent of thyroxin hormone.

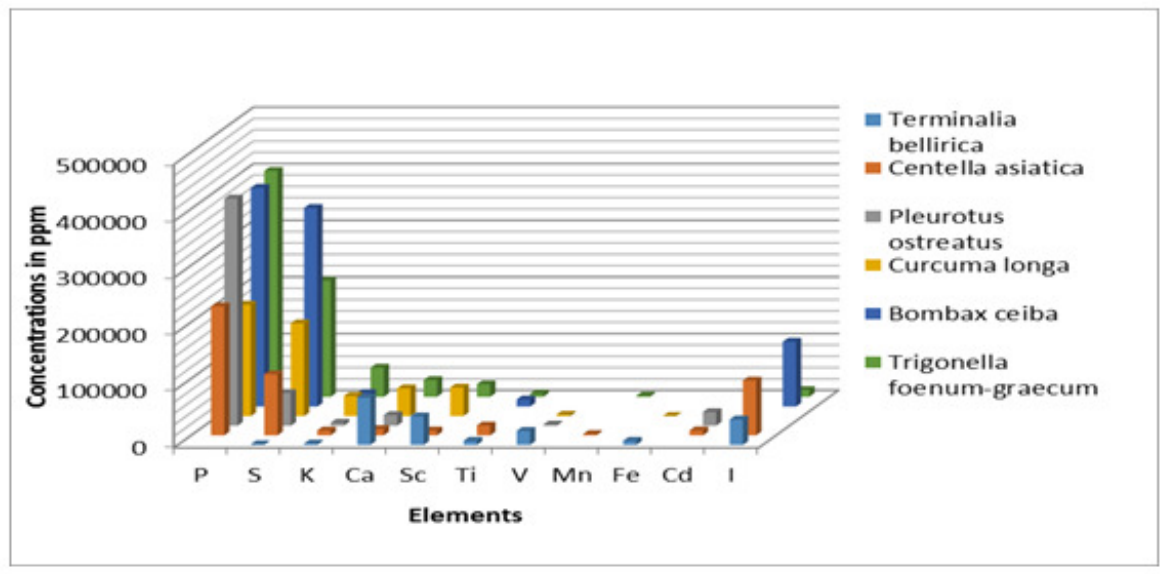

Figure 1. Bar chart for elements found in the medicinal plant samples and corresponding concentrations.

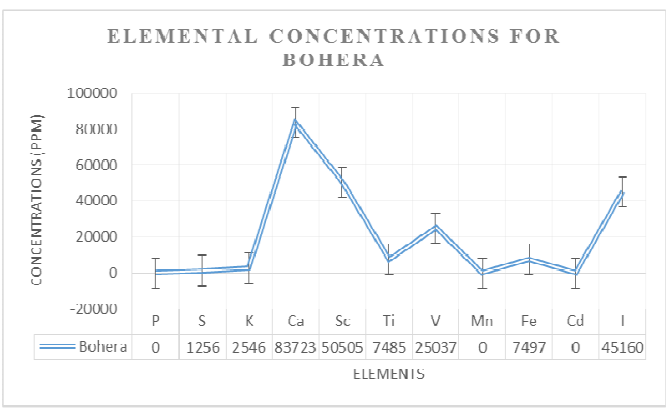

Figure 2.1: Elemental concentration for Bohera

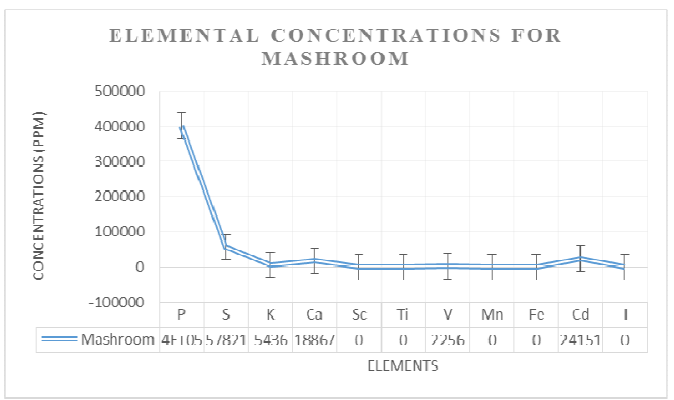

Figure 2.3: Elemental concentration for Mashroom

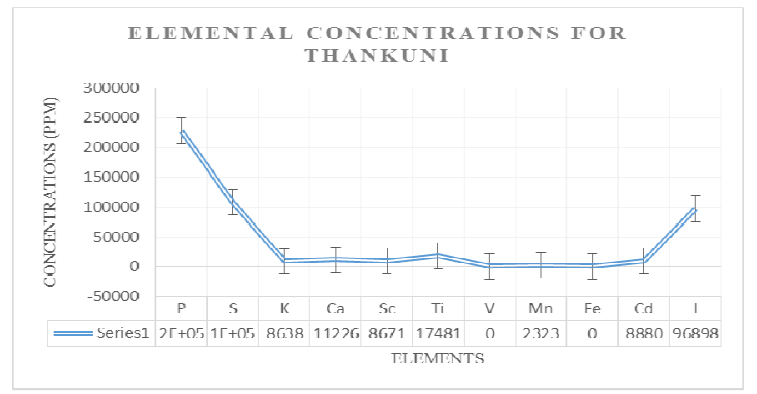

Figure 2.2: Elemental concentration for Thankuni

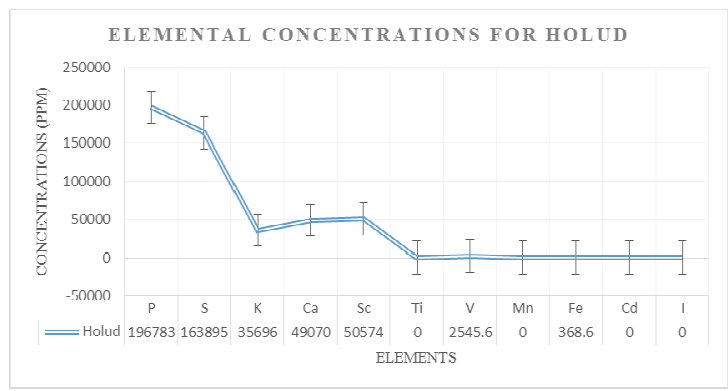

Figure 2.4: Elemental concentration for Holud 


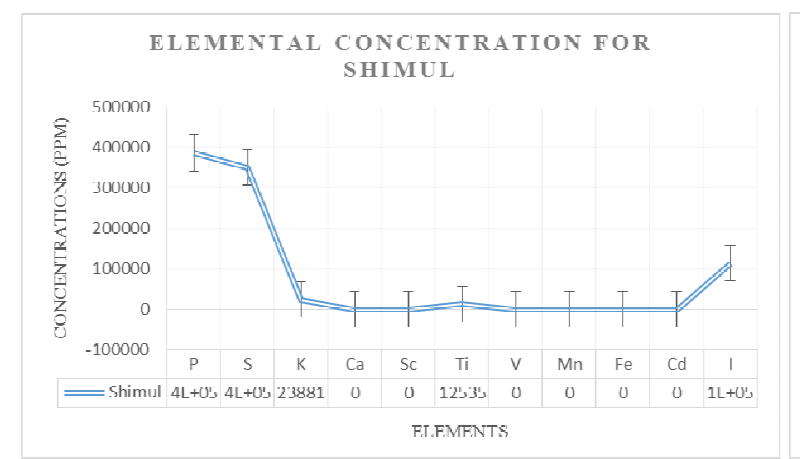

Figure 2.5: Elemental concentration for Shimul

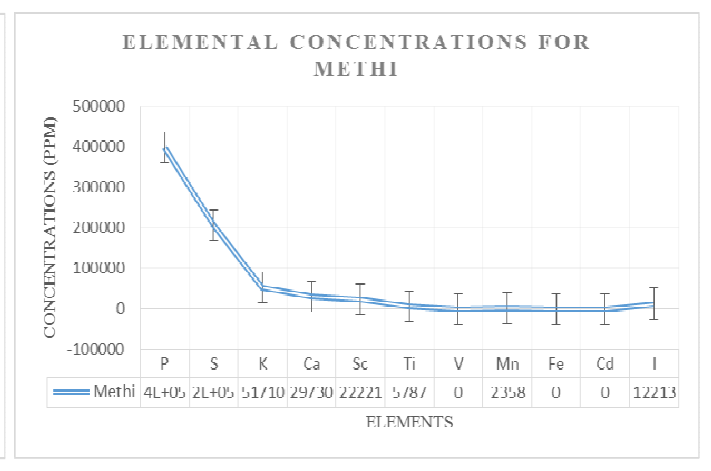

Figure 2.6: Elemental concentration for Methi

Vanadium is present in three plants of which Terminalia bellirica contains maximum concentration of $25036.9 \mathrm{mg} / \mathrm{kg}$. Vanadium is another trace element which can improve insulin sensitivity, normalize blood pressure, regulate cholesterol and triglyceride levels in blood [19]. Now a days vanadium is using for treating diabetes mellitus. Also it works for the protection of tissues against any damage [20,21]. Manganese, iron and cadmium were detected only in two of the six medicinal plants. The highest amount of manganese is $2358.4 \mathrm{mg} / \mathrm{kg}$ in Trigonella foenum-graecum. A small amount of this micronutrient is enough for performing as an enzyme stimulator and metalloenzymes component. Manganese is also important for urea cycle and fatty acids and cholesterol metabolism and urea cycle [22]. The highest measured concentration of iron is $7497.3 \mathrm{mg} / \mathrm{kg}$ in Terminalia bellirica. It is one of the most important trace elements whose major functions are transport of oxygen to the tissues and processes of cellular respiration. Iron strengthens the function of stomach [1]. Cadmium, another trace element, is present in Pleurotus ostreatus with the maximum amount of $24150.7 \mathrm{mg} / \mathrm{kg}$. Cd is considered as nonessential element for animals [23]. Cadmium absorption from stomach and intestines are practically substandard and therefore, this element has no poisonous effect on human body.

\section{Conclusions}

Ion beam analytical technique PIXE was implemented to trace out the concentration of different elements contained in six selected medicinal plants of Bangladesh, i.e., Bohera (Trminalia bellirica), Thankuni (Centella Asiatica), Mashroom (Pleurotus ostreatus), Holud (Curcuma longa), Shimul (Bombax ceiba) and Methi (Trigonella foenumgraecum), which are of great interest in curative purposes. The concentrations of most of the elements are really high. This is because Savar is an industrial area where environment is extremely polluted for the disposal of industries wastes hither and thither in an unplanned way. However, further similar study may unveil the cause behind it if any other than pollution.

\section{ACKNOWLEDGEMENTS}

The Authors are highly indebted to Atomic Energy Center, Dhaka for giving us permission to carry out this study at its Accelerator Facilities Division. We also pay our gratitude to all the staff of Accelerator Facilities Division for their prompt helping hand. 


\section{REFERENCES}

1. Hossen M. L,Azharul Islam S. M et al.,(2014)"Elemental profile analysis of some traditionalmedicinal plants of Bangladesh using PIXE technique", Journal of Nuclear and Particle Physics, Vol.4, No.5, pp 137-141.

2. Jabeen S, Shah M. T. et al., (2010) "Determination of major and trace elements in ten important folk therapeutic plants of Haripur basin, Pakistan”, J Med Plant Res, Vol. 4, No. 7, pp 559-566.

3. Rajurkar N. S., Damame M. M (1998) "Mineral content of medicinal plants used in the treatment of diseases resulting from urinary tract disorders", Applied Radiation and Isotopes. Vol. 49, No. 7, pp773-776.

4. Hashmi D. R, Ismail S, Shaikh G. H, (2007) "Assessment of the level of trace metals in commonly edible vegetables locally available in the markets of Karachi city”, Pak. J. Botany, Vol. 39, No. 3), pp 747.

5. Nazarudeen A. (2010) "Nutritional composition of some lesser-known fruits used by ethnic communities and local folks of Kerela”, Ind. J. Traditional Knowl, Vol. 9, No. 2, pp 398-402.

6. Johanson S. A. E. and Campbell J. L, (1988) "PIXE, A Noble Technique for Elemental Analysis", Wiley, Chichester.

7. Khaliquzzaman M., Lam S. T. et at., (1983) "Dependence of X-ray yields on different parameters for light elements matrices in thick target PIXE and use of standards for calibration for such analysis", Nuclear Instruments and Methods in Physics, Vol. 216, pp 481-488.

8. Akselsson K. R., Johansson S. A. E. et al., (1976) Proceedings of ERDA symposium on x- and gamma-ray sources and applications, Ann Arbor Science Publ. Inc., pp 175.

9. Fahad S. M., Abedin M. J. et al., (2014) "Study of elemental profile of some medicinal plants of Bangladesh", Journal of Nuclear and Particle Physics, Vol. 4, No. 1, pp 1-6.

10. Maxwell J. A., Campbell J. L., Teesdale W. T., (1989) "The Guelph PIXE software package”, Nuclear Instruments and Methods in Physics Research Section B: Beam Interactions with Materials and Atoms, Vol. 43, No. 2, pp 210-230.

11. Maxwell J. A., Teesdale W. T., Campbell J. L., (1995) "The Guelph PIXE software package II", Nuclear Instruments and Methods in Physics Research Section B: Beam Interactions with Materials and Atoms, Vol. 95, No. 3, pp 407-421.

12. Gaugh L. P., Shacklette H. T., Case A. A., et al., (1979) "Element Concentrations Toxic to Plants, Animals, and Man”, U. S. Govt. Printing Office, Washington, D.C. Geological Survey Bulletin, pp 46.

13. He F. J., MacGregor G. A., (2008) "Beneficial effects of potassium on human health". Physiologia Plantarum, Vol. 133, No. 4, ppn725-735.

14. DRI Dietary Reference Intakes for Calcium, Phosphorus, Magnesium, Vitamin D, and Fluoride, (1997) Food and Nutrition Board, Institute of Medicine, National Academy Press, Washington, D.C.

15. Theobald H. E., (2005) "Dietary calcium and health", British Nutrition Foundation, Nutrition Bulletin, Vol. 30, pp 237-277.

16. González C. S., Chaves C. L., et al., (2013) "Accumulation of Scandium in Plasma in Patients with Chronic Renal Failure”, The Scientific World Journal, Vol. 2013, pp 1.

17. Frisken K. W., Dandie G. K., Lugowski S., (2002) "A study of titanium release into body organs following the insertion of single threaded screw implants into the mandibles of sheep", Australian Dental Journal, Vol. 47, pp 214-217.

18. Prashanth L., Kattapagari K. K., Chitturi R. T., Baddam V. R., Prasad L. K., (2015) “A review on role of essential trace elements in health and disease", Journal of Dr. NTR University of Health Sciences, Vol. 4, pp 75-85.

19. Gruzewska K., Michno A., Pawelczyk T., Bielarczyk H., (2014) "Essentiality and toxicity of vanadium supplements in health and pathology", Journal of Physiology and Pharmacology, Vol. 65, pp 603-611.

20. Sivarajan V. V., Balachandran I., (1994) Ayurvedic Drugs and their Plant Sources, Oxford \& IBH Publishing Co. Pvt. Ltd., New Delhi.

21. Sizer F., Whitney E., (2013) Nutrition: concepts and controversies, Wadsworth Cengage Learning. 
International Journal of Recent Advances in Physics (IJRAP) Vol.5, No.3/4, November 2016

22. Rehnberg G. L., Hein J. F., Carter S. D., Linko R. S., Laskey J.W., (1982), "Chronic ingestion of Mn3O4 by rats: Tissue accumulation and distribution of manganese in two generations", Journal of Toxicology and Environmental Health, Vol. 9, pp 175-188.

23. Gaugh L. P., Shacklette H. T., Case A. A., et al., (1979) "Element Concentrations Toxic to Plants, Animals, and Man”, U. S. Govt. Printing Office, Washington, D.C. Geological Survey Bulletin, pp 15 .

\section{Authors}

Md.Lokman Hossen,born in Bangladesh in the year 1989,obtained BSc an MS Degree majoring in physics from Jahangirnagar University. Currently he is working as a lecturer at Physics Department in University of Barisal for about two years.His research interest is High Energy Particle Physics(accelerator).

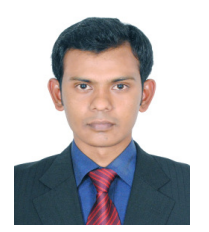

